OPEN ACCESS

Edited by:

Yan-ling Wang,

Institute of Zoology (CAS), China

Reviewed by:

Takashi Yazawa,

Asahikawa Medical College, Japan

Tsubasa Sakai,

Suntory Foundation for Life

Sciences, Japan

*Correspondence:

Dan-Qi Lu

ludanqi@mail.sysu.edu.cn

Specialty section:

This article was submitted to Experimental Endocrinology,

a section of the journal

Frontiers in Endocrinology

Received: 02 October 2017 Accepted: 31 January 2018

Published: 26 February 2018

Citation:

Peng $W$, Sun $Y, L i G-F, H e L-G$,

Li R-Z, Liang Y-S, Ding $X, Y u X$, Zhang Y, Lin H-R and Lu D-Q (2018)

Two Distinct Interferon- $\gamma$ in the

Orange-Spotted Grouper (Epinephelus coioides): Molecular Cloning, Functional Characterization, and Regulation in Toll-Like Receptor Pathway by Induction of miR-146a.

Front. Endocrinol. 9:41.

doi: 10.3389/fendo.2018.00041

\section{Two Distinct Interferon- $\gamma$ in the Orange-Spotted Grouper (Epinephelus coioides): Molecular Cloning, Functional Characterization, and Regulation in Toll-Like Receptor Pathway by Induction of miR-146a}

\author{
Wan Peng 1,2,3, Yan Sun ${ }^{1}$, Gao-Fei Li ${ }^{1}$, Liang-Ge He ${ }^{1}$, Ruo-Zhu Li', Yao-Si Liang ${ }^{1}$, Xu Ding ${ }^{1}$, \\ Xue Yu' ${ }^{1}$, Yong Zhang ${ }^{1}$, Hao-Ran Lin ${ }^{1}$ and Dan-Qi Lu ${ }^{1 *}$ \\ 'State Key Laboratory of Biocontrol, Institute of Aquatic Economic Animals, Guangdong Provincial Key Laboratory for
Aquatic Economic Animals, College of Life Sciences, Sun Yat-Sen University, Guangzhou, China, ${ }^{2}$ Sun Yat-Sen University
Cancer Center, State Key Laboratory of Oncology in South China, Collaborative Innovation Center for Cancer Medicine, \\ Guangzhou, China, ${ }^{3}$ Department of Experimental Research, Sun Yat-Sen University Cancer Center, Guangzhou, China
}

Interferon gamma (IFN $\gamma$ ) is a Th1 cytokine that is critical for innate and adaptive immunity. Toll-like receptors (TLRs) signaling pathways are critical in early host defense against invading pathogens. miR-146a has been reported to participate in the regulation of host immunity. The known mechanisms of integrations between the IFNy and TLR signaling pathways are incompletely understood, especially in teleosts. In this study, orange-spotted grouper (Epinephelus coioides) IFN $\mathrm{N} 1$ and IFN $\gamma 2$, their biological activities, especially their involvements in TLR pathway, were explored. We identified and cloned two IFN $\gamma$ genes of E. coioides, namely EcIFN 1 and ECIFN 2 2. The produced recombinant E. coioides IFN 1 (rECIFN $\gamma 1)$ and IFN $\gamma 2$ (rECIFN $\gamma 2)$ proteins showed functions, which are similar to those of other bony fishes, such as enhancing nitric oxide responses and respiratory burst response. rEcIFN 22 could regulate TLR pathway by enhancing the promoter activity of miR146a upstream sequence and thus increasing the expression level of miR-146a, which possibly targets TNF receptor-associated factor 6 (TRAF6), a key adapter molecule in TLR signaling pathway. Taken together, these findings unravel a novel regulatory mechanism of anti-inflammatory response by IFN $\gamma 2$, which could mediate TLR pathway through IFN 2 2-miR-146a-TRAF6 negative regulation loop. It is suggested that IFN $\gamma 2$ may provide a promising therapeutic, which may help to fine tune the immune response.

Keywords: Epinephelus coioides, IFN $\gamma 1$, IFN $\gamma 2$, miR-146a, TNF receptor-associated factor 6

Abbreviations: IFN $\gamma$, interferon gamma; TLR, toll-like receptor; rEcIFN $\gamma 1$, recombinant E. coioides IFN $\gamma 1$; rEcIFN $\gamma 2$, recombinant $E$. coioides IFN $\gamma 2$; TRAF6, TNF receptor-associated factor 6; IRAK1, interleukin-1 receptor-associated kinase 1; UTR, untranslated region; ORF, open reading frame; NLS, nuclear localization sequences; TCM, tissue culture medium; PAMPs, pathogen-associated molecular patterns; IFN $\gamma \mathrm{R}$, IFN $\gamma$ receptor. 


\section{INTRODUCTION}

Interferon gamma (IFN $\gamma$ ) is a Th1 cytokine that is critical for almost all phases of immune and inflammatory responses. Only one single IFN $\gamma$ gene is identified in mammalian (1), avian (2), and amphibian (3) species, while many fishes possess two IFN $\gamma$ genes, namely IFN $\gamma 1$ and IFN $\gamma 2$. Like mammalian IFN $\gamma$, teleost IFN $\gamma$ s mediate their protective effects as an activator of macrophages, through the enhancing of respiratory burst activity, nitric oxide production, and bacterial phagocytosis (4-8), inducing of the expression of pro-inflammatory cytokines $(4,5,9)$ and the typical antiviral genes $(8,10)$. Respiratory burst and nitric oxide are well known as potent antimicrobials (11).

Orange-spotted grouper (Epinephelus coioides) is one of the most commercially important species in Southeast Asian. However, along with the rapid development of aquaculture industry, diseases caused by viruses, bacteria, and parasites emerge more and more frequently and have led to great number of economic loss. Injection of Poly(I:C), an interferon inducer, or recombinant IFNal protein could provide significant protection against viruses in sevenband grouper (Epinephelus septemfasciatus) $(12,13)$. In addition, inactivated Singapore grouper iridovirus vaccine, which showed high efficiency in orange-spotted grouper, could induce the expression of type I interferon-stimulated genes, suggesting that type I interferon system may be involved in the antivirus immune responses (14). Taken together, it was suggested that interferons might play important roles in the immune system of groupers, while the function of IFN $\gamma$ and its potential applications in grouper farming are still unclear and worth investigating.

Toll-like receptors (TLRs), a family of evolutionarily conserved receptors, play crucial roles in early host defense against invading pathogens. IFN $\gamma$ was produced by natural killer and $\mathrm{T}$ cells during the recognition of pathogens by TLRs (15). Like mammalian IFN $\gamma$ (16), teleost IFN $\gamma$ s also play various roles in response to bacterial or viral infection $(8,9,17,18)$. IFN $\gamma$ and TLR signaling pathways are important for both innate and adaptive immune responses. However, the cross talk between IFN $\gamma$ and TLR signal pathways is incompletely understood.

MicroRNAs (miRNAs) are conserved small non-coding RNAs that function as posttranscriptional regulators of gene expression by binding to the $3^{\prime}$ untranslated region (UTR) of target mRNAs (19-22). The genesis of miRNAs was mediated by a two-step processing pathway, in which long primary miRNAs are first processed to approximately 60-bp hairpin precursor miRNAs (pre-miRNAs), then, these pre-miRNAs are cleaved to generate mature miRNAs $(23,24)$. miR-146a has been reported to participate in the regulation of host immunity (25-28). miR-146a, whose transcription is controlled by NF-KB and is induced by TLR activation, negatively regulates the TLR pathway by targeting TNF receptor-associated factor 6 (TRAF6) and interleukin-1 receptor-associated kinase 1 (IRAK1), which are key adapter molecules in TLR signaling cascades, mediating activation of NF-kB pathway (29-34).

In the present study, we report the cloning, expression profiles of $E$. coioides IFN $\gamma 1$ and IFN $\gamma 2$ and their potential functions in regulation of immune response. First, the functional recombinant E. coioides IFN $\gamma 1$ ( $\mathrm{rEcIFN} \gamma 1)$ and recombinant $E$. coioides IFN $\gamma 2$
$(\mathrm{rEcIFN} \gamma 2)$ proteins were obtained. We detected their ability of enhancing respiratory burst activity, nitric oxide production. Then the potential cross talk between $E$. coioides IFN $\gamma$ s and TLR pathway was explored. Our data demonstrated that $\mathrm{r} E c \mathrm{IFN} \gamma 2$ could regulate TLR pathway by enhancing the miR-146a upstream sequence transcription activity and thus increasing miR-146a expression, while miR-146a may target TRAF6. These findings unravel a novel regulatory mechanism of anti-inflammatory response by IFN $\gamma 2$, which may function as novel negative regulator and promising therapeutic that help to fine tune the immune response.

\section{MATERIALS AND METHODS}

\section{Ethics Statement}

All animal experiments were conducted in accordance with the guidelines and approval of the Animal Research and Ethics Committees of Sun Yat-Sen University. All efforts were made to minimize suffering.

\section{Fish}

Healthy E. coioides weighing approximately $500 \mathrm{~g}$ were purchased from the Guangdong Daya Bay Fishery Development Center (Huizhou, Guangdong, P. R. China). The fish were maintained in a recirculating seawater system, with a $12 \mathrm{~h}$ light/ $12 \mathrm{~h}$ dark cycle, at $25-30^{\circ} \mathrm{C}$ for 7 days before use. The fish were fed with commercial pellets twice daily. Food was withheld from the fish for $24 \mathrm{~h}$ prior to sample collection. All of the fish used in this study appeared to be healthy before the experiments were conducted. Before sample collection, the fish were anesthetized with MS-222 in dechlorinated water for $2 \mathrm{~min}$.

\section{Molecular Cloning}

The head kidney was dissected from healthy E. coioides, and total RNA was extracted by TRIzol reagent (Invitrogen, USA). The first strand of cDNA was synthesized with ReverTra Ace qPCR RT Kit (TOYOBO, Japan) according to the manufacturer's instructions.

The open reading frame (ORF) regions of IFN 1 and IFN 2 were amplified with the primers listed in Table 1. PCR amplification were performed at $94^{\circ} \mathrm{C}$ for $5 \mathrm{~min}$, followed by 40 cycles at $94^{\circ} \mathrm{C}$ for $20 \mathrm{~s}, 55^{\circ} \mathrm{C}$ for $20 \mathrm{~s}$, and $72^{\circ} \mathrm{C}$ for $45 \mathrm{~s}$, with $72^{\circ} \mathrm{C}$ for a final $10 \mathrm{~min}$ at the end of the last cycle. All PCR products were ligated into the pTZ57R/T Vector (Fermentas, USA) after analyzing on $1.5 \%$ agarose gels, finally sequenced by Invitrogen Bioengineering Corporation, Guangdong, China.

The upstream sequence of pre-miR-146a was cloned from E. coioides genomic DNA using the primers of miR-146a F/R (Table 1). The pre-miR-146a upstream fragment was ligated into pGL4.10[luc2] vector (Promega, USA). Mutated versions of these constructs were obtained by site-directed mutagenesis using Mut Express II Fast Mutagenesis Kit (Vazyme, China).

TNF receptor-associated factor $63^{\prime}$ UTR was cloned from head kidney cDNA by PCR with the primers of TRAF6 F/R (Table 1). To create 3'UTR luciferase reporter constructs, fragments of 3'UTR of TRAF6 gene were sub-cloned downstream of CMV-driven firefly luciferase cassette in pMIR-REPORT vector (Ambion, USA). 
TABLE 1 | List of primer sequences.

\begin{tabular}{|c|c|c|}
\hline Primers & Sequence $5^{\prime}-3^{\prime}$ & Information \\
\hline IFN $\gamma 1$ open reading frame (ORF)-F & ATGTCTTCGTGTTGTGGATC & IFN $\gamma 1$ ORF cloning \\
\hline IFN $\gamma 1$ ORF-R & AGAAACAGTTCCCAGCACC & \\
\hline IFN $\gamma 2$ ORF-F & TGTCTCCGTCCTGAGCATC & IFNy2 ORF cloning \\
\hline IFN $\gamma 2$ ORF-R & AGATITGTCATTAAACACCCTC & \\
\hline IFN $\gamma 1$ Ndel-F & GGAATTCCATATGTCTAGGATTCCATG & Recombinant construct \\
\hline IFN $\gamma 1$ Xhol-R & CCGCTCGAGGCGTCGTTCAGCAGA & \\
\hline IFN $\gamma 2$ EcoRI-F & CCGGAATTCGTCCCACATCCCTCAGGAGAT & Recombinant construct \\
\hline IFN $\gamma 2$ Xhol-R & CCGCTCGAGGGCTCTCTGATGAGTIITGA & \\
\hline IFN $\gamma 1$ FD & CGATTCGGTCATCAAGAGCAT & Real-time PCR \\
\hline $\mathrm{IFN} \gamma 1 \mathrm{RD}$ & CTCCGTCACGACCGACACCA & \\
\hline IFN $\gamma 2$ FD & CAGCAATGGTGAGGTGGCA & \\
\hline IFN $\gamma 2$ RD & TाTGTCTGGATGATAGGGTC & \\
\hline $18 \mathrm{~S} \mathrm{~F}$ & CCTGAGAAACGGCTACCACATCC & \\
\hline $18 S \mathrm{R}$ & AGCAACTITAGTATACGCTATTGGAG & \\
\hline TNF receptor-associated factor 6 (TRAF6) F & GGTGGCAGTAACATGGCAAG & TRAF6 3'untranslated region cloning \\
\hline TRAF6 R & GCTATITGTGTCAGTGTTGTCTCA & \\
\hline $\operatorname{miR}-146 a \mathrm{~F}$ & TTGAATACACCCCTATCAGACATC & The upstream of mature miR-146a cloning \\
\hline miR-146a R & AGTAAGGCTGACAAACAAGTACCA & \\
\hline
\end{tabular}

\section{Bioinformatics}

BLAST was used for identifying CDNA and deducing amino acid sequences in the NCBI. ${ }^{1}$ Prediction of ORF were performed in the DNAssist 2.0 software. Multiple-sequence alignment of the $E c I F N \gamma$ with other vertebrate IFN $\gamma s$ were performed with the Clustal Omega. ${ }^{2}$ A vertebrata IFN $\gamma$ phylogenetic tree was constructed with MEGA6 software using the maximum likelihood (ML) method, with a bootstrap of 100 times to verify its credibility. The SignalP program ${ }^{3}$ was applied to search for the signal peptide of vertebrata IFN $\gamma$. $\mathrm{N}$-glycosylation sites were predicted by NetNGlyc ${ }^{4}$ and nuclear localization sequences (NLS) were predicted by Brameier et al. (35). Target prediction between miR-146a and the 3'UTR region of TRAF6 was performed using FINDTAR3. Sequences of mature miR-146a were obtained from our lab by whole genome sequencing. The pre-miR-14a was confirmed by structure prediction using RNAfold WebServer. ${ }^{5}$

\section{Expression Study}

Twelve tissues including the thymus, head kidney, trunk kidney, spleen, heart, gill, eye, skin, intestine, stomach, skin, and liver were aseptically dissected from three independent individuals. The tissue expression profiles were detected by real-time PCR performed with SYBR Green PCR Master Mix (Life Technologies, USA) and the primers of IFN $\gamma 1 \mathrm{~F} / \mathrm{R}$ or IFN $\gamma 2 \mathrm{~F} / \mathrm{R}$, respectively. E. coioides $18 \mathrm{~S}$ rRNA (18S-F/R) was amplified as an internal control (Table 1).

\section{Production and Purification of rEcIFN $\gamma$ Proteins}

The putative mature peptides of E. coioides IFN $\gamma 1$ and IFN $\gamma 2$ were predicted by the SignalP program. Then, the cDNA fragments encoding the putative mature peptide with deletion of the the signal peptide from the $\mathrm{N}$ terminus were amplified by PCR using the primers of IFN $\gamma 1$ NdeI-F/IFN $\gamma 1$ XhoI-R and IFN $\gamma 2$ EcoRI-F/IFN $\gamma 2$ XhoI-R (Table 1), respectively. The fragments were separated on a $1.5 \%$ agarose gel and purified by Qiagen gel extraction kit (Qiagen, Germany). After subcloning into pTZ57R/T vector for sequencing, the fragments were digested with restriction enzymes and then inserted into the pET22b expression vector (Novagen, USA). The E. coli BL21 (DE3) cells transformed with IFN $\gamma 1$ recombinant construct and E. coli Rosetta (DE3) cells transformed with IFN $\gamma 2$ recombinant construct were induced by different concentrations of IPTG. The cells were collected by centrifugation and the resultant recombinant proteins named $\mathrm{rEcIFN} \gamma 1$ and $\mathrm{rEcIFN} \gamma 2$ were purified using His.Bind Column (Novagen) according to the manufacturer's protocol. The purity of $\mathrm{rEcIFN} \gamma \mathrm{s}$ was checked on SDS-PAGE gel stained with coomassie brilliant blue R-250 (Sigma, USA), and the size of target proteins was measured by comparing the protein band location with a standard protein (Fermentas). Both proteins were detected by western blotting using a primary antiHis-tag monoclonal antibody (Novagen) and a secondary goat anti-mouse IgG (Amersham Biosciences, UK).

\section{Isolation of Blood Lymphocytes and Head Kidney Monocytes}

The whole blood of fish was directly obtained from three fish $(n=3)$ using $5 \mathrm{~mL}$ syringe. Blood lymphocytes were isolated from whole blood using lymphocyte separation medium. The primary head kidney cells were obtained as previously described (36). Head kidney monocytes were isolated from primary head kidney 
cells using monocyte isolating kit (TBDscience, China). The isolated cells were washed and enumerated on a hemocytometer with trypan blue and resuspended at a concentration of $10^{6}$ cells/ $\mathrm{mL}$ in tissue culture medium (TCM). The TCM was prepared from RPMI-1640 medium by adding 10\% fetal bovine serum (Life Technologies), 2 mM L-glutamine (Sigma), and penicillin/ streptomycin (Sigma).

\section{Nitric Oxide Assay}

Primary blood lymphocytes were distributed into 96-well plates at a density of $10^{6}$ cells/mL. $\mathrm{rEcIFN} \gamma 1$ or $\mathrm{r} E c \mathrm{IFN} \gamma 2$ were respectively added to the culture medium to reach a working concentration of 1,10 , and $100 \mathrm{ng} / \mathrm{mL}$, and the control group was treated with TCM. These cells were incubated at $28^{\circ} \mathrm{C}$ in $5 \%$ $\mathrm{CO}_{2}$ for $72 \mathrm{~h}$. Nitrite production was determined based on the Griess reaction with a NO determination kit (Beyotime Institute of Biotechnology, China).

\section{Respiratory Burst Assay}

Primary blood lymphocytes cultivation and in vitro stimulation were performed as described in Nitric oxide assay. The respiratory burst assay was performed as previously described (8). These cells were incubated at $28^{\circ} \mathrm{C}$ in $5 \% \mathrm{CO}_{2}$ for $18 \mathrm{~h}$. Then, NBT $(2 \mathrm{mg} / \mathrm{mL}$, Sigma) and PMA (final concentration, $100 \mathrm{ng} / \mathrm{mL}$, Sigma) were added to the cell cultures at room temperature. Absolute methanol was applied to fix the pelleted cells, and 70\% methanol was applied to remove the non-reduced NBT. After air drying, the reduced NBT was dissolved using $2 \mathrm{M} \mathrm{KOH}$ and the blue crystals in the cytoplasm were dissolved by DMSO. Finally, the OD values were detected at $630 \mathrm{~nm}$.

\section{Western Blot}

Primary head kidney cells were distributed into 6-well plates at a density of $10^{6}$ cells/mL. $\mathrm{rEcIFN} \gamma 1$ or $\mathrm{rEcIFN} \gamma 2$ were, respectively, added to the culture medium to reach a working concentration of 1,10 , and $100 \mathrm{ng} / \mathrm{mL}$, and the control group was treated with TCM. After incubation for $3 \mathrm{~h}$ at $28^{\circ} \mathrm{C}$ in $5 \% \mathrm{CO}_{2}$, these cells were washed with PBS and lysed in a lysis buffer (Beyotime), which contained protease inhibitors (Sigma) and phosphatase inhibitors (Sigma). The protein lysates were separated by SDS-PAGE, then transferred onto nitrocellulose membranes. The membranes were blocked in 5\% BSA in TBST for $1 \mathrm{~h}$ at room temperature followed by incubations with primary antibodies and the relevant HRP-conjugated secondary antibodies. The membranes were processed for ECL Western Blotting Detection Reagents (Pierce). Meanwhile, the TRAF6 expression levels in primary head monocytes after $r E c I F N \gamma 1$ or $r E c I F N \gamma 2$ treatment were also detected by western blot. Antibodies used in the study were TRAF6 (Santa Cruz, CA, USA) and $\beta$-actin (Proteintech, USA). The bands were analyzed semiquantitively by densitometry (grayscale analysis) with ImageJ software and normalized to their controls.

\section{miR-146a Expression Levels Detection}

After treatment with $\mathrm{rEcIFN} \gamma 1$ or $\mathrm{rEcIFN} \gamma 2$, head kidney monocytes were collected. Total RNA was extracted by TRIzol reagent (Invitrogen), then reverse-transcribed and amplified with the Hairpin-it miRNAs RT-PCR Quantitation kit (GenePharma,
China). E. coioides U6 snRNA served as control. The relative level of miR-146a expression was calculated using the comparative threshold (2- $\left.{ }^{-\Delta \Delta \mathrm{Ct}}\right)$ method (37).

\section{Detection of the Relationship between miR-146a and TRAF6}

In order to confirm whether miR-146a could directly target the mRNA of TRAF6, HEK-293T cells were transfected with $40 \mathrm{nM}$ miR-146a mimics (GenePharma) or negative control (nc) (GenePharma) using Lipofectamine 2000 (Invitrogen) according to the manufacturer's protocol. $24 \mathrm{~h}$ after transfection, luciferase activity in 293T cells was measured using the Dual-Luciferase Reporter Assay System (Promega) according to the manufacturer's instructions. The luciferase data were normalized by dividing the firefly luciferase activity by the activity of Renilla luciferase.

Primary head kidney monocytes were also transfected with miR-146a mimics or nc. The cells were lysed and the TRAF6 protein levels in the lysates were detected with western-blot.

\section{Pre-miR-146a Upstream Sequence Activity Assay}

Mutant or wild-type pre-miR-146a upstream-reporter vectors were transfected into $293 \mathrm{~T}$ cell using Lipofectamine 2000. After $6 \mathrm{~h}$, the cells were stimulated with $\mathrm{rEcIFN} \gamma 1$ or $\mathrm{rEcIFN} \gamma 2$ and luciferase activities were measured.

\section{Statistical Analyses}

All data were expressed as mean values \pm SEM. Statistical analysis was carried out by one-way analysis of variance (ANOVA) or $t$-test. Differences were considered significant with a $p$-value less than 0.05 and were marked with asterisks.

\section{RESULTS}

\section{Cloning and Sequence Characterization of EcIFN $\gamma 1$ and $E c I F N \gamma 2$ Genes}

The ORF of the $E c I F N \gamma 1$ and $E c I F N \gamma 2$ genes transcript was obtained (Figure 1). $E c$ IFN $\gamma 1$ ORF was 567 bp in length and translated into a 188 -aa precursor molecule with a 19-aa signal peptide, while $E c I F N \gamma 2$ ORF was 603 bp in length and encoded a 200 -aa putative protein with a 19 -aa signal peptide. The predicted mature $E c I F N \gamma 1$ peptides contain two potential $N$-glycosylation sites (NTS and NVT), while EcIFN $\gamma 2$ have one $N$-glycosylation site (NRT). Furthermore, $E c I F N \gamma 1$ and $E c I F N \gamma 2$ both possess an IFN $\gamma$ signature sequence ([I/V]-Q-X-[K/Q]-A-X2-E-[L/F]-X2$[\mathrm{I} / \mathrm{V}])$ at the $\mathrm{C}$-terminus, which was conserved among known IFN $\gamma$ molecules. In particular, a conserved motif RRRRRR similar to the nuclear localization signal of the known IFN $\gamma$ molecules is found in $E c I F N \gamma 2$ at its C-terminal tail, which was absent in $E c I F N \gamma 1$.

\section{Homology Alignment and Phylogenetic Analysis}

Both $E c I F N \gamma 1$ and $E c I F N \gamma 2$ sequences and the IFN $\gamma$ s from other species were subjected to multiple alignment (Figure 2). The alignment confirms that $E c I F N \gamma 1$ and $E c I F N \gamma 2$ have relatively low 


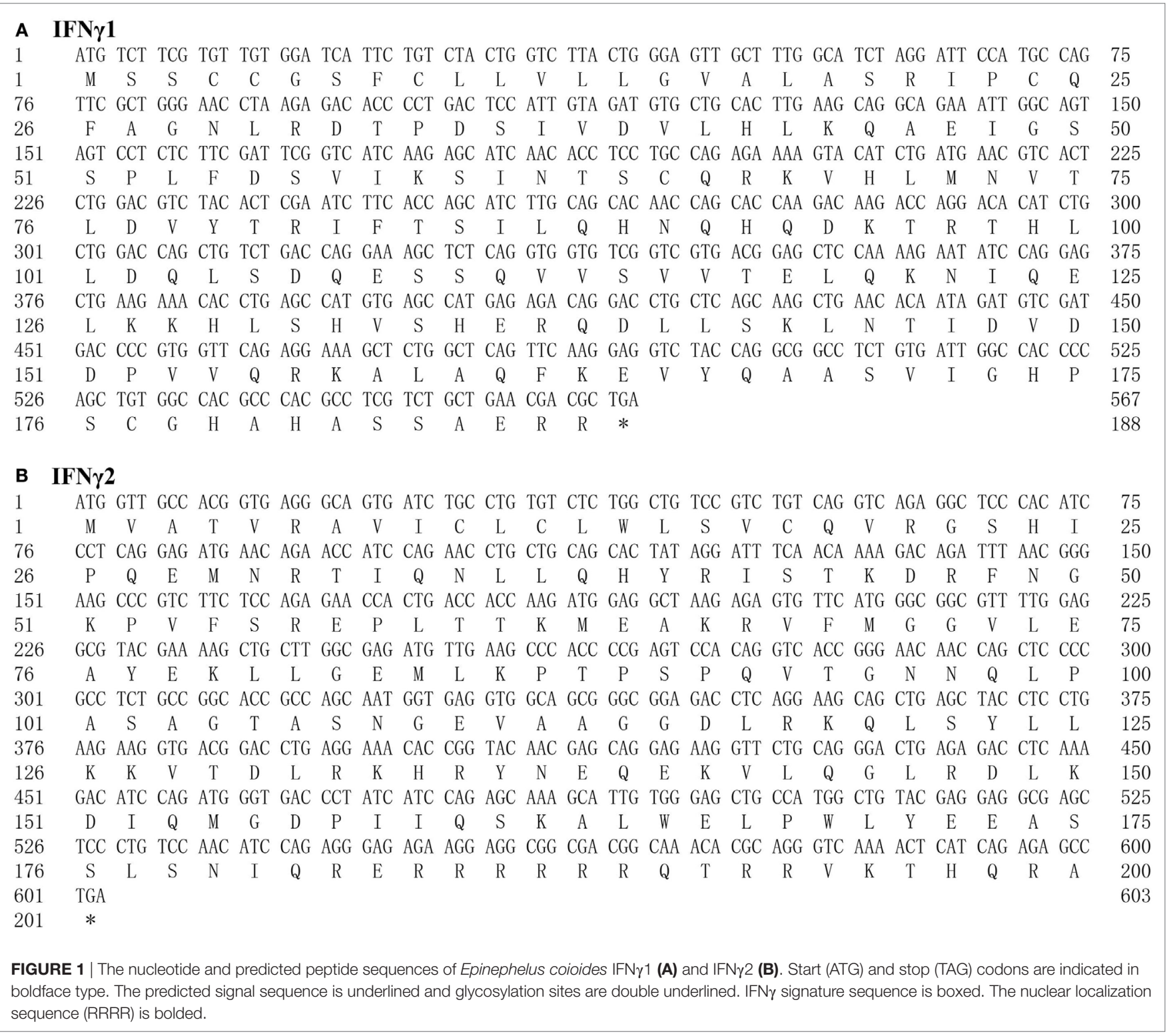

sequence similarity compared with their vertebrate counterparts, respectively. $E c I F N \gamma 1$ has $18.42-44.89 \%$ amino acid identity with other known fish IFN $\gamma 1$, which shared the highest degree with tetraodon (Tetraodon nigroviridis) $(44.89 \%)$. EcIFN $\gamma 2$ shared a higher similarity with teleosts IFN $\gamma 2$ sequences varied from 25.15 to $61.86 \%$ than with other vertebrates (12.41-22.02\%), being most similar to IFN $\gamma$ from Japanese flounder (Paralichthys olivaceus) (61.86\%).

A phylogenetic tree was also constructed based on the alignments of $E c I F N \gamma 1$ and $E c I F N \gamma 2$ sequences with that of other species (Figure 3). The EcIFN $\gamma 1$ was branched with T. nigroviridis. $E c I F N \gamma 2$ was most closely related to those of $P$. olivaceus and T. nigroviridis, all of which belonged to marine teleost IFN $\gamma 2$ clade. The previously reported rainbow trout (Oncorhynchus mykiss) IFN $\gamma 1$ might also belong to the IFN $\gamma 2$ family based on the phylogenetic tree and protein alignments.

\section{Expression Profile of EcIFN $\gamma 1$ and EcIFN $\gamma \mathbf{2}$} Quantitative expression analysis of $E c I F N \gamma 1$ or $E c I F N \gamma 2$ in tissues of healthy fish revealed that $E c I F N \gamma 1$ and $E c I F N \gamma 2$ mRNA were expressed in different patterns. The highest mRNA levels of $E c I F N \gamma 1$ were in the thymus and intestine, while the expression was relatively low in stomach, heart, eye, and spleen (Figure 4A). EcIFN $\gamma 2$ was globally expressed in almost all tissues, and its expression levels were higher in gills and spleen, but lower in intestine, head kidney and eye (Figure 4B).

\section{Prokaryotic Production of rIFN $\gamma 1$ and rIFN $\gamma 2$}

For further study of the biological activities of $E c I F N \gamma 1$ and $E c I F N \gamma 2$, the two putative mature peptides were expressed as C-terminal 6 His-tagged fusion protein in BL21 (DE3) and 


\section{A IFN $\gamma 1$}

Epinephelus coioides IFNy1 Tetraodon nigroviridis IFNy1 Danio rerio IFNy1-1 Ictalurus punctatus IFNy1 Cyprinus carpio IFNy1

Epinephelus coioides IFN $\gamma 1$ Tetraodon nigroviridis IFNy1 Danio rerio IFNy1-1 Ictalurus punctatus IFN $\gamma 1$ Cyprinus carpio IFNy1

\section{B IFN $\gamma 2$}

Epinephelus coioides IFNy2 Oncorhynchus mykiss IFNy1 Oncorhynchus mykiss IFNy2 Tetraodon nigroviridis IFNy2 Danio rerio IFNy1-2 Ictalurus punctatus IFNy2a Ictalurus punctatus IFN $2 \mathrm{~b}$ Cyprinus carpio IFNy2a Cyprinus carpio IFNy2b Paralichthys olivaceus IFNy Xenopus tropicalis IFNy Crocodylus porosus IFNy Gallus gallus IFNy Taeniopygia guttate IFNy Ornithorhynchus anatinus IFNy Sus scrofa IFNy Mus musculus IFNy Rattus norvegicus IFNy Homo sapiens IFNy

Epinephelus coioides IFNy2 Oncorhynchus mykiss IFNy1 Oncorhynchus mykiss IFNy2 Tetraodon nigroviridis IFNy2 Danio rerio IFN $\gamma 1-2$ Ictalurus punctatus IFNy2a Ictalurus punctatus IFNy2b Cyprinus carpio IFN $2 \mathrm{a}$ Cyprinus carpio IFN $2 \mathrm{~b}$ Paralichthys olivaceus IFNy Xenopus tropicalis IFNy Crocodylus porosus IFNy Gallus gallus IFNy Taeniopygia guttate IFNy Ornithorhynchus anatinus IFNy Sus scrofa IFNy Mus musculus IFNy Rattus norvegicus IFN Homo sapiens IFNy
MSSCCG---SFCLLV----LLGVALASRIP-----CQFAGNLR-DTPDSIVDVLHLKQAEIGSSPLFDSV IKS INTSCQRK--VHLMNVTLDVYTRIFTSILQHNQHQDKTRTHLLDQLS ----MS---PLCLLF---LLGAVGTSQAS-----FQFISQMLKKDHEVVAHALKLTQVEFIAGPLFSSVIRNVNSSCQRRDDVQMMSTTLDVYDRIFSSIQKQKEQQDQAD-TLLSQVP MDSCLK-MVLLCGLLWIASLQTTSAYRFRRSRSENP-_-ILN-TNIEKLKTHYNTLAKDWVGKSVFVSHLDQLNSKPTCTCQAVLLEGMLSIYEDIFQDMMNKSD MGSWSN-VLLMCGLVMVALLNGTTGHEIH---_--NLT-EAVHTLQIHHGLTDTKWVGKAVFTPYLGKV--EDTCTCEKLVLLRMLNGYMDIFSDMLKKAK MYCWLNYVHLICALLLIVSLQGTVGARLPQSQNDKEQMLKNLR-EKIEPLQKHYHTTDKEWFGKSVLLSHLHQLNSKASCTCQSLLLDRYLNITETILQDLRGKAE
. :

$\therefore \quad * \quad *: .:$ :

DQESSQVVSVVTELQKNIQELKKHLSHVSHERQDLLSKLNTIDVDDPVVQRKALAQFKEVVQAASVIGHPSCGHAHAS-SAERR PSQRSEVESALQHLQQRMKTLKGKLKQMNEKREEELDRLKTIEVDDVLVQKKALAQFKAVYYAASLIGH--CGHALSD--------NKEVRDDLKKVIHEVKNLKHKYNEE-HKLWRELQDIHSVKAKNGTIQERALNDFLKVYYRASTEKRHLHMS---_-_-_---TVETETSLKELQESVKELKNKYNNE-QAVWKQLHEINTVKKDDSTIQGGAVNDFISV|YDKAFVVAQHSKKTPLLLKHFLQR ---NEETKTRLTDVMTEVKILRHKYSEE-QKVWRELQDIHSVEVKNGTNQKGALNSFLILYDLAY

-WVAT---VRAVICLCL--WL-SVCQ-VRGSHIPQEMNRTIQNLLQHYRISTK---D-RFNGKPVFSREPLTT----KMEAKRVFMGGVLEAYEKLLGEMLKPTPSPQVTGNNQLPASA --- MDVLSRAVMCFCLMGWM-TLGWSNAAQFTSINMKRNIDKLKVHYKISKD---Q-LFNGNPVFP-----KDTFEDSDRRVLMSVVLDVYLSIFGQMLNQTGDQE-----MDVLSRAVMCFCLMGWM-TLGWSNAAQYTSINMKRNIDKLKVHYKISKD---Q-LFNGNPVFP------KDTFEDSEQRVLMSVVLDVYLSIFSQMLNQTGDQE -MVAR- - VTTVMGWCL-CM-ALCQ-VKGSYIPADMNRTIQNLLDHYKIPDR---E-RFNGHPIFPRGPSSG---DLQAEMIYMSAVLQTYDQLLNQMLQQLPTATPTSAS-----MIAQHMMGFAWGVCLLFSGWM-TYSE----ASVPENLDKSIEELKAYYIKEDS---Q-LHNAHPIFLRILKDLKVNLEESEQNLLMSIVMDTYSRIFTRMQNDSVDEA-MTLFWRICFVFFGMM-AYSE---A-AFLPKNIKESIDHLNNHYVRKNPNPGK-LYDGHSLFLDKLT--KQKFEESEQKLLMTIILDAYNKIFTKMENETQDET MTLFWRICFVFFGMM-AYSE-- - AFLPKNIKESIDHLNNHY---NPNPGK-LYDGHSLFLDKLT--KQKFEESEQKLLMTIILDAYNKIFTKMENETQDET -MTAQNTMAFFWGVCLLTSGMM-TYGE----ASVPENLDKSIDELKAYYIKDDH---E-LHNAHPVFLRALKDLKVNLEEPEQNLLMSIIMDTYSRIFTRMENDSLDEA-MTAQNTMAFFWGVCLVTLGQM-TYGE----ASVPENLDKSIDELKVYYIKDDR---E-LHNAHPVFLRFLKDIKVNLEEPEQNLLMSI IMDTYSRIFTQMEKDSQDEAMMVST-- -MRQYRLLSLFVIIYWVGHIHGSSVNIREASTATEELRKHFNKINQ---DDDDSTGLIFLKLFDSWK---EEGEKKILLSQIVPVYLKMLDAIPKIPELQAMTYQTYLFIFLSVHLSCLGCLES-TIIPFQVQSDIDKLKIDFNSSNS---D-VADGGPIFTEKLKSWT---EVNERRILFSHIISLYLKMFESIDTSKAHI-MTCQTYNLFVLSVIMIYYGHTAS-SLNLVQLQDDIDKLKADFNSSHS---D-VADGGPIIVEKLKNWT---ERNEKRIILSQIVSMYLEMLENTDKSKPHI MAFQTYSLFVLSVIMIFFGHVEN-RLNLLQLQNDIDKLKADFNSSHS---D-VADGGPIFTERLSSWT---ERNEKRIILSQIVSMYLKMFENTDRSKAHV MNYPAAFCVLQFGIVICLSGFAH-GFSFSLLSNEIDNLKEYYNASEP---D-VAEDGPLFVMMLKDAQ---QD-EKKVILSQIISMYLDIFSTLEDNHLVK MSYTTYFLAFQLCVTLCFSGS----YCQAPFFKEITILKDYFNASTS---D-VPNGGPLFLEILKNWK---EESDKKIIQSQIVSFYFKFFEIFKDNQAIQ-MNATHCILALQLFLM-AVSGC----YCHGTVIESLESLNNYFNSSGI---D-V-EEKSLFLDIWRNWQ---KDGDMKILQSQIISFYLRLFEVLKDNQAIS

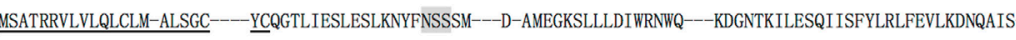
MKYTSYILAFQLCIVLGSLGC----
GTASNGEVAAGGDLRKQLSYLLKKVTDLRKHRYNEQ-EKVLQGLRDLKDIQMGDPI I QSKALWEQ PWLYEEASSLSNIQR-- ERRRRRRQTRRVKTHQRA--MIESLKYVKGKIQDLQKHYFLGRIPELRTHLQNLWAIETSDTTVQGKALSEA ITIYEKASKLALKFHLKKDNRRKRRQAQRLKSSHIM---VRERLDQVKGKVQETQKHYFLGRVPELRTHLQNLWAIKTSDTTV QGKALSEP ITIYEKASKLAHEIHLKKDNRRKRRQAQRLKSHIM----_-TSTSTSTSLRAQLSYLLKKITALRTQYYRKH-EELLKKLQPLGNVQLTSTVY QSKALWEL IKVYQEASSLPDRLELRRRRRR---QAQVKGHRRA--TKERLAHVQEHLKKLQESYFPGKSAELRTYAETLWA IKENDP IV QRKALFEL KRVYREATLLKN---LKNKE-RKRRQAKASRSKSLNRG -LKNHLHEVKDQMNKLKEHYFSGKHADIKKYVTELLDLKENDPRIQSKAIFEL KAVYNKATNLGR- -MSAENPRRRRQAKSSKKQHS--LKNHLHEVKDQMNKLKEHYFSGKHADIKKYVTELLDLKENDPRIQSKAIFEL KAVYNKATNLGR--MSAENPRRRRQAKSSKKKQHS---TKERLAHVQEHLKKLKENYFPGKSAELKTYAETLWAIKEDDPVI IRKALFEI KRVYREATQLRN---LKNKE-RRRRQAKITKKQKS---TKEKLAHVQEHLEKLQENYFPGKSAELKTYAETLWAIKEDDPVV QRKALFEL KRVYREATQLKN - - LKNKE-RRRRQARITKKQKS--SREGLNSAAPEVSVRTDLNYILKKVQELRTNRFKEQ-SKLLQGLHDLGD IKMNNFI I QSKALWEL QWMYEEASSLSNNTKMQRRRRRRRRQARKVKTPTRA--SIKNLKMMLHTSFEDLLK-QSDQKLRGLHELKKIQVGDVKT QHAAIKEL FMILRELSVMEQPKNHVVKKRKLDFQQRNRKRRNRLF-RNVHEYLL-AKKSNLA-NDYKKINDIMELAKLPTSDLKI QRKAINEL SPLLQKLDSPTGR--SERRRR-Q-NPRGCKC-----KHISEELY-TLKNNLP-DGVKKVKDIMDLAKLPMNDLRI QRKAANEL FSILQKLVDP-PS--FKRKRS-Q-SQRRCNC-----RNIAEELS-TLKESLS-DGSKKIEDLRDLTNLQUSDLKV QRKAVNEL FSVLQKLGDTSSS--YKRKRS-Q-FQRLCKC---_-ESMGKIRESMVQWNQT-HGFKKLGDLQKLIKTSVSDAKI QRKAVHEL FWVFQNLHNMTANSSQRKKRRS-R-QRISKY----_-RSMDVIKQDMFQRFLN-GSSGKLNDFEKLIKIPVDNLQI QRKAISEL IKVMNDL---SPRSNLRKRKRS-Q-TMFQGQRASK---NNISVIESHLITTFFS-NSKAKKDAFMSIAKFEVNNPQVRQAFNEL IRVVHQL---LPESSLRKRKRS-R-C--NNISVIESHLITNFFS-NSKAKKDAFMSIAKFEVNNPQI QHKAVNEL IRVIHQL---SPESSLRKRKRS-R-C--KSVETIKEDMNVKFFN-SNKKKRDDFEKLTNYSVTDLNV QRKAIHEL IQVMAEL---SPAAKTGKRKRS-Q-MLFRGRRASQ---

FIGURE 2 | Continued 
FIGURE 2 | Multiple alignments of Epinephelus coioides IFN $\gamma 1$ (A) and IFN $\gamma 2$ (B). A multiple alignment of the deduced amino acid sequences of E. coioides IFN 1 and IFN $\gamma 2$ with those of other mammalian and piscine sequences was created using the ClustalX program. The putative signal peptides are indicated by single underlines. The signature motif ([IV]-Q-X-[KQ]-A-X2-E-[LF]-X2-[IV]) is boxed. The N-glycosylation sites are shaded in gray. The nuclear localization sequences sequence is in bold. Identical amino acids among all sequences are indicated by "*," whereas those with high or low similarity are indicated by ":" and ".". Amino

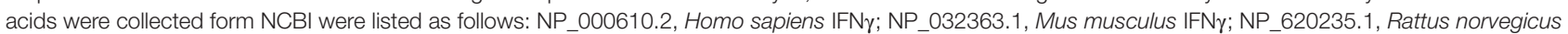

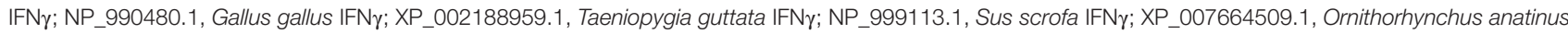

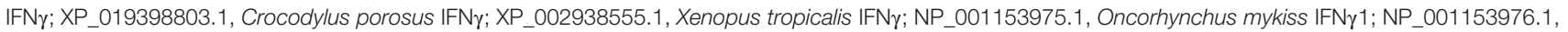

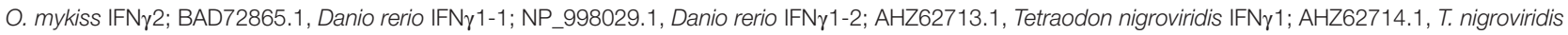

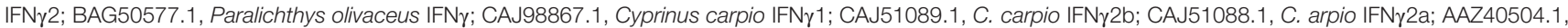

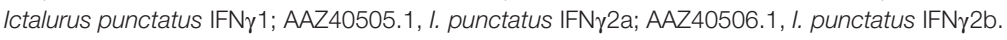

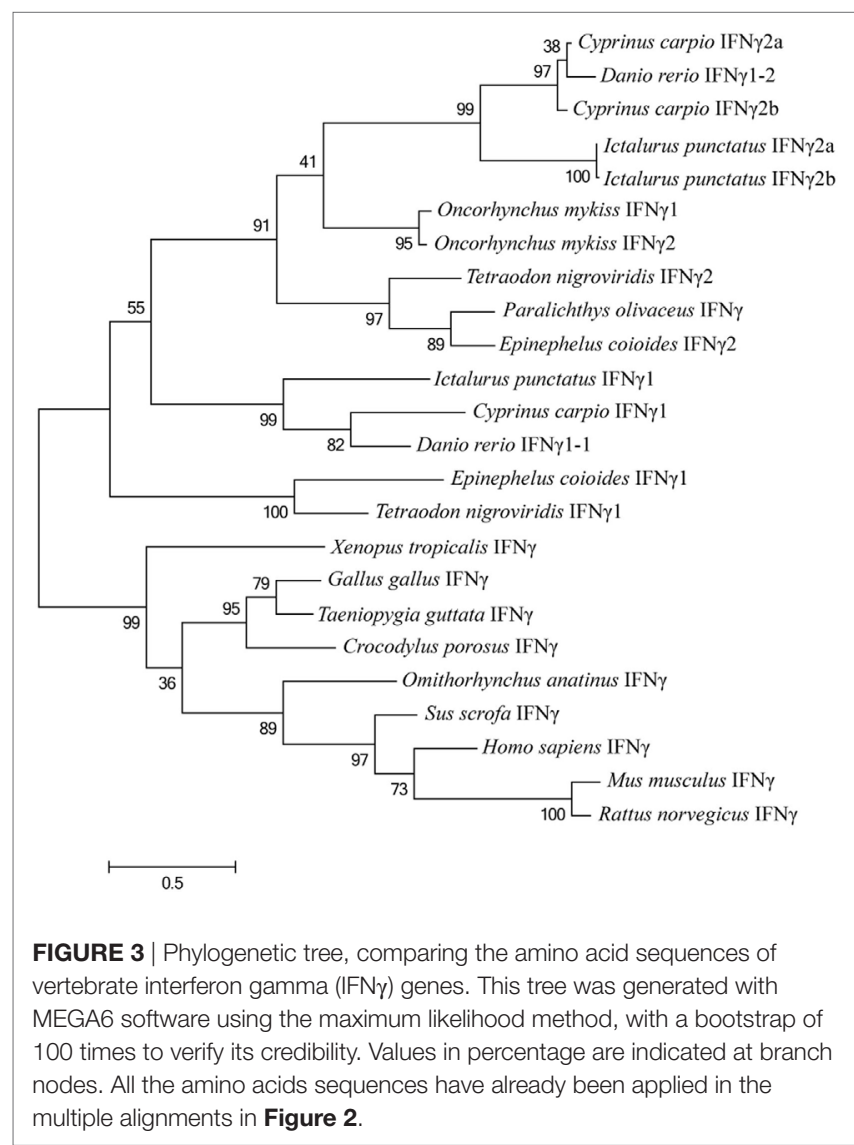

Rosetta (DE3) cells, respectively, followed by purification with affinity chromatography. SDS-PAGE analysis (Figures 5A,B) indicated that the purified sample exhibited a single protein band after induction by IPTG, and the molecular weights were close to the predicted size of the 6-His fused $\mathrm{r} E c \mathrm{IFN} \gamma 1$ and $\mathrm{r} E c \mathrm{IFN} \gamma 2$ peptides, respectively. Besides, both $\mathrm{rEcIFN} \gamma 1$ and $\mathrm{rEcIFN} \gamma 2$ were confirmed by Western blot assay with monoclonal antibody against the His-tag, and a single band was detected for the each of fused proteins (Figure 5C).

\section{rEcIFN $\gamma 1$ and rEcIFN $\gamma 2$ Activated Nitric Oxide Responses and Respiratory Burst Response}

Blood lymphocytes were exposed to different concentrations of $\mathrm{r} E c \mathrm{IFN} \gamma 1$ or $\mathrm{r} E c \mathrm{IFN} \gamma 2$, followed by detection of the respiratory burst or nitric oxide levels. Both $\mathrm{r} E c \mathrm{IFN} \gamma 1$ and $\mathrm{rEcIFN} \gamma 2$ at concentrations of 1 and $10 \mathrm{ng} / \mathrm{mL}$ induced nitric oxide responses in blood lymphocytes that were significantly higher than that of none recombinant protein treatment (Figure 6A). In addition, $\mathrm{r} E c I F N \gamma 1$ or $\mathrm{rEcIFN} \gamma 2$ at $1 \mathrm{ng} / \mathrm{mL}$ induced an obvious respiratory burst response in blood lymphocytes (Figure 6B).

\section{rEcIFN $\gamma 1$ and rEcIFN $\gamma 2$ Induced miR-146a Expression Level by Enhancing the miR-146a Upstream Region Activity}

The miR-146a expression level was detected by real-time PCR. Compared to the control group, the expression level of miR-146a in group with $\mathrm{rEcIFN} \gamma 1$ or $\mathrm{rEcIFN} \gamma 2$ treatment was significantly increased at 0.5 and $2 \mathrm{~h}$ (Figure 7A). miR-146a expression level reached a peak (increased approximately 11 -fold) at about $2 \mathrm{~h}$ after $\mathrm{r} E c$ IFN $\gamma 2$ treatment. The rapid induction of miR-146a in response to $\mathrm{rEcIFN} \gamma 1$ or $\mathrm{rEcIFN} \gamma 2$ suggested that miR-146a might be involved in response to IFN $\gamma$.

We first identified the stem loop of E. coioides pre-miR-146a (Figure 7B). Then, approximately $2.5 \mathrm{~kb}$ genomic region upstream of mature miR-146a was analyzed. Two gamma-activated sequence (GAS, TTNCTTTAA) were found, namely 300 GAS ( -198 to $-190 \mathrm{bp})$ and $1300 \mathrm{GAS}(-1,136$ to $-1,128 \mathrm{bp}$ ) (Figure 7C). To explore the relationship between GAS and E. coioides IFN $\gamma$ s, the miR-146a upstream approximately $2.5 \mathrm{~kb}$ fragment was inserted into pGL4.10 vector. Dual-luciferase report assay was conducted after transfection with wild-type or mutant pGL4-miR-146a vectors followed by $r E c I F N \gamma 1$ or $r E c I F N \gamma 2$ stimulation. The miR146a upstream region luciferase activity significant increased after $\mathrm{rEcIFN} \gamma 2$ treatment (Figure 7D). Upon mutantion of either GAS, $r E c I F N \gamma 2$ had no effect on luciferase activity of miR-146a upstream region.

\section{miR-146a May Target TRAF6}

To further investigate the effect of miR-146a induction, we predicted its mRNA target sites. 3'UTR of TRAF6 mRNA was found to contain miR-146a target sequences (Figure 8A). In mammals, TRAF6 are key adapter molecules in TLR receptor signaling cascades, mediating activation of NF- $\mathrm{\kappa B}$ pathway. To test the possibility that the TRAF6 expression may be regulated posttranscriptionally by miR-146a, we constructed a reporter vector that contained the firefly luciferase gene fused to $900 \mathrm{bp}$ of the $3^{\prime} \mathrm{UTR}$ region of TRAF6 containing putative miR-146 target site. The reporter construct was transiently transfected into $293 \mathrm{~T}$ cells together with miR-146a mimics. Compared to 

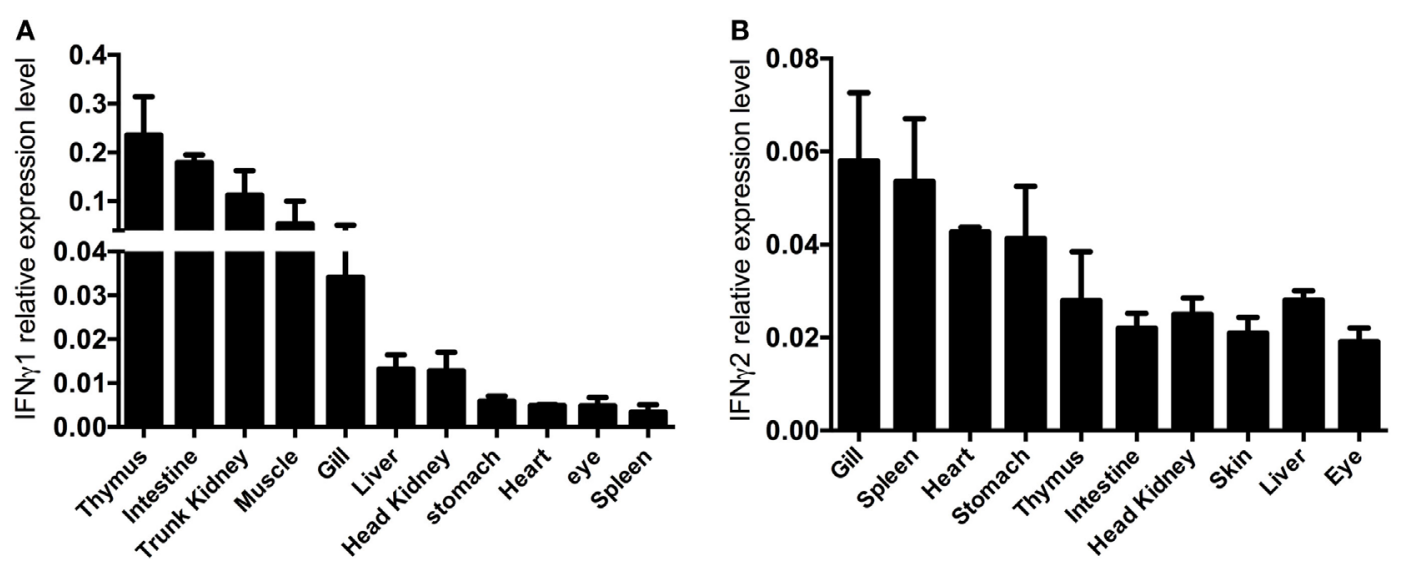

FIGURE 4 | Constitutive interferon gamma (IFN $\gamma$ ) expression. cDNA of different organs of four control fish were used as template for quantitative real-time PCR. The $\mathrm{IFN} \gamma 1$ (A) and IFN $\gamma 2$ (B) mRNA expression data are shown relative to the 18S rRNA.

nc, a significant downregulative effect in the relative luciferase activity was observed when cells were transfected with miR-146a mimics (Figure 8B). We further examined the effect of miR-146a on TRAF6 protein expression in primary head kidney monocytes of E. coioides. After miR-146a mimic treatment, miR-146a mRNA expression was found to increase, which suggested that miR-146a mimics was successfully transfected into the primary head kidney monocytes (Figure 8C). The western blot results showed that TRAF6 protein level decreased after miR-146a mimics transfection (Figure 8D). These data suggested that the TRAF6 gene might be the target for posttranscriptional repression by miR-146a.

\section{rEcIFN $\gamma 1$ and rEcIFN $\gamma 2$ Regulated TRAF6 Expression}

Compared to the control group, both $\mathrm{rEcIFN} \gamma 1$ and $\mathrm{rEcIFN} \gamma 2$ treatments obviously induced TRAF6 protein expression from 0.5 to $2 \mathrm{~h}$. After $4 \mathrm{~h}, \mathrm{rEcIFN} \gamma 1$ treatment slightly increased the TRAF6 protein expression, while $\mathrm{r} E c \mathrm{IFN} \gamma 2$ treatment resulted in slight decrease (Figure 9).

\section{DISCUSSION}

IFN $\gamma 1$ and IFN $\gamma 2$ are already identified in various teleosts. However, their immune functions, especially their involvement in TLR pathway, remained unclear. In this research, the biological activities of $\mathrm{r} E c \mathrm{IFN} \gamma 1$ and $\mathrm{r} E c \mathrm{IFN} \gamma 2$ were preliminarily characterized. We demonstrated that E. coioides IFN $\gamma 1$ and IFN $\gamma 2$ not only functioned similarly to those of other bony fishes but could also mediate TLR pathway through IFN $\gamma 2$-miR-146a-TRAF6 negative regulation loop.

EcIFN $\gamma 1$ shares highest sequence similarity with T. nigroviridis (44.89\%) IFN $\gamma 1$ molecules and lower similarity with IFN $\gamma 2$ proteins. In bony fish, IFN $\gamma 2$ shows higher sequence similarity with marine fishes generally than freshwater fishes and shares highest identity with $P$. olivaceus $(61.86 \%)$. Based on the relatively low similarity between species, it might be suggested that IFN $\gamma$ s of different species play different roles. However, the protein tertiary structure of the whole IFN $\gamma$ s family as six $\alpha$-helices remained conserved. Besides, a conserved motif ([IV]-Q-X-[KQ]-A-X2E-[LF]-X2-[IV]) could be found in $E c I F N \gamma 1, E c I F N \gamma 2$ and all the other known IFN $\gamma$ s. The C-terminal cationic motif RRRRRR is found in EcIFN 2 , which is similar to its mammalian counterparts. This motif is considered as the NLS region that plays indispensable role in IFN $\gamma$ functioning. Loss of NLS resulted in a failure of the inducing ability of $\mathrm{rIFN} \gamma$ on IP-10 expression in O. mykiss (7).

$E c I F N \gamma 1$ and $E c I F N \gamma 2$ present ubiquitous and constitutive expression in many tissues of teleost fish but show different expression patterns. In Atlantic cod (Gadus morhua) and Atlantic halibut (Hippoglossus hippoglossus L.), IFN $\gamma 2$ is mainly expressed in gills and spleen, while its expression levels are low in stomach and liver $(18,38)$. In common carp (Cyprinus carpio L.) and goldfish, IFN $\gamma 2$ is ubiquitously expressed in almost all tissues, while the highest expression levels could be found in immune organs as well $(5,39)$. In channel catfish (Ictalurus punctatus), IFN $\gamma 1$ was found to be highly expressed in the thymus and intestines, while IFN $\gamma 2$ was found to be only expressed in head kidney (40). In contrast, in rainbow trout, IFN $\gamma 1$ mRNA transcription profile is similar to IFN $\gamma 2$, both of whom were highly expressed in gills and spleen, with lower expression in head kidney and skin (7), which further suggested that the rainbow trout IFN $\gamma 1$ might belong to IFN $\gamma 2$ family.

In this study, $E c I F N \gamma 1$ and $E c I F N \gamma 2$ gene showed broad expression in all sampled tissues. EcIFN $\gamma 1$ was expressed at highest level in thymus and intestines while EcIFN $\gamma 2$ in spleen and gills, suggesting the two IFN $\gamma$ genes might participate in signaling pathways of both immune and in non-immune tissues to resist pathogens in different manner probably.

Although recombinant proteins produced from E. coli generally lack glycosylation, whether the functions of interferons rely on glycosylation or not remains unclear. In black carp, it was reported that the un-glycosylated mutation form of IFN $\alpha$ could still be secreted and showed the similar antiviral ability as that of normal IFN $\alpha$ (41). For IFN $\gamma$, it was found that the unglycosylated IFN $\gamma$ suffered from shorter half-life and lower protease resistance, while 

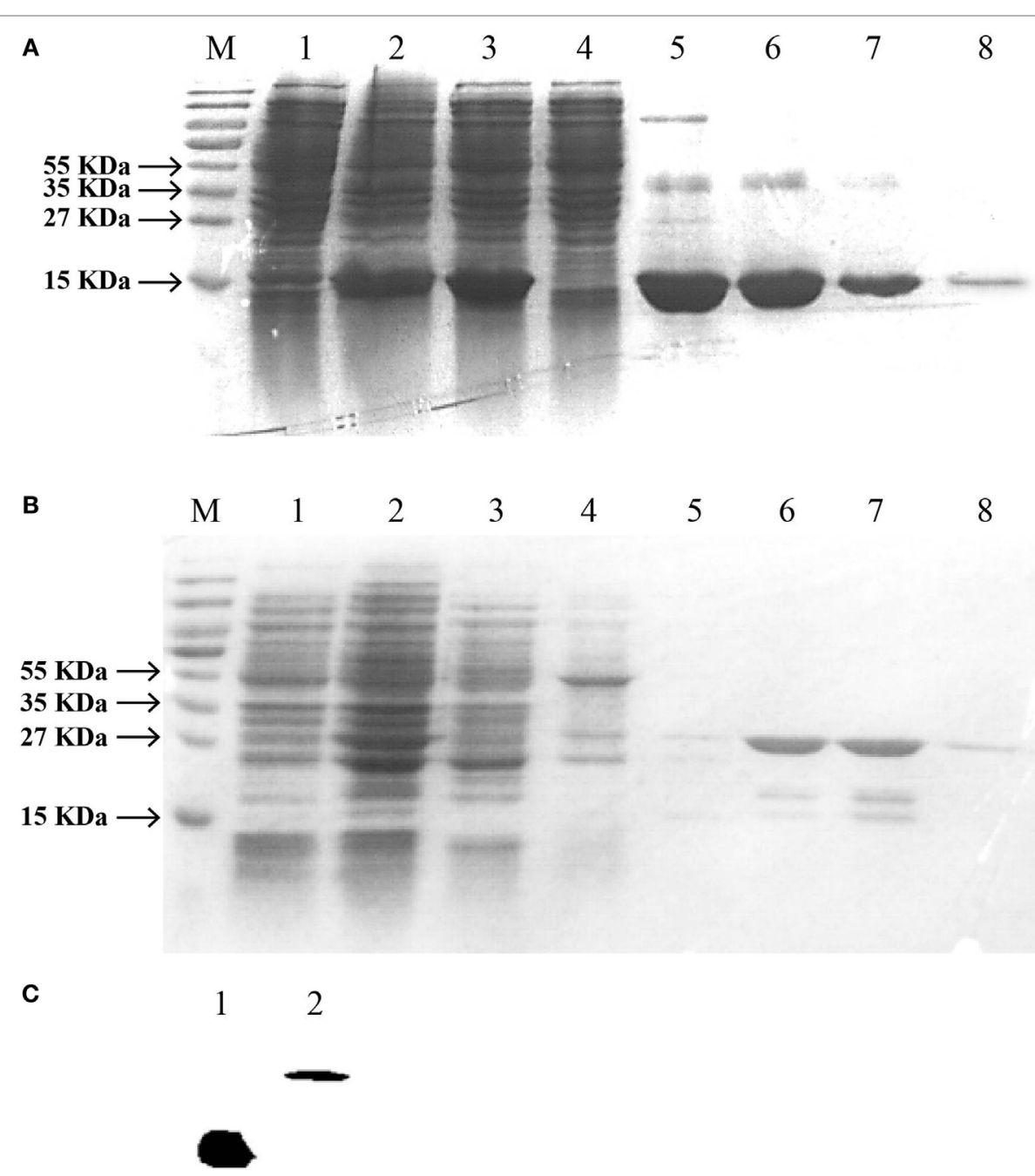

FIGURE 5 | SDS-PAGE and western blotting analysis of Epinephelus coioides interferon gamma (IFN $\gamma$ ). IFN $\gamma 1$ (A) or IFN $\gamma 2$ (B) proteins was expressed using the pET22b expression vector. (A) Lane M: protein size marker; Lane 1: the total lysates from non-induced cells; Lane 2: the total lysates from IPTG-induced cells; Lane 3: soluble IFN 1 protein; Lane 4-7: IFN 1 protein by washing buffer with different imidazole concentration; Lane 8: purified recombinant protein with a His-tag; (B) Lane M: protein size marker; Lane 1: the total lysates from non-induced cells; Lane 2: the total lysates from IPTG-induced cells; Lane 3: soluble IFNy2 protein; Lane 4-8: IFN 2 protein by washing buffer with pH6.3, pH5.9, pH5.4, pH5.0, and pH4.5. (C) Verification of recombinant IFN $\gamma 1$ and IFN $\gamma 2$ by Western blot. Lane 1: IFN 1 ; Lane 2: IFN $\gamma 2$; they were analyzed on a 15\% SDS-PAGE gel, followed by western blotting analysis using a mAb against the His-tag. The molecular weight of the lane 1 IFN $\gamma 1$ was the same to that of the lane 8 of Figure 5A. Similarly, that of lane 2 IFN $\gamma 2$ was also the same to the lane 8 of Figure $5 \mathbf{B}$.

its function seemed to be unchanged (42). Functional in vitro assays exhibited that $\mathrm{rEcIFN} \gamma 1$ and $\mathrm{r} E c \mathrm{IFN} \gamma 2$ could induce nitric oxide response, which effects are similar with the previous researches from mammals, goldfish, tetraodon, and common carp, in which, IFN $\gamma$ were found to induce a nitric oxide response $(5,6,8,39,43)$. Meanwhile, both $\mathrm{rEcIFN} \gamma 1$ and $\mathrm{rEcIFN} \gamma 2$ significantly enhanced the respiratory burst response, which effects were also observed in mammalian, goldfish and rainbow trout IFN $\gamma s(5-7,44)$. These results suggested that the rEcIFN $\gamma 1$ and $\mathrm{rEcIFN} \gamma 2$ obtained from E. coli have normal biological activities similar to those of the type II interferons of other teleosts.

After $\mathrm{rEcIFN} \gamma 1$ or $\mathrm{rEcIFN} \gamma 2$ treatment, the expression of TRAF6 protein was first upregulated, which lasted for $2 \mathrm{~h}$ and then gradually decreased to the basic level. It suggested that there might also exist a cross talk between IFN $\gamma$ and TLR signaling pathway in teleost. In mammals, IFN $\gamma$ regulates TLR signaling components (45) by including positive TLR signaling components, such as TLR itself, signaling adaptors MyD88 and IRAK1 $(46,47)$, and inhibitory TLR signaling components, such as SOCS1 and SOCS3 (48). IFN $\gamma$ also could modulate the expression of ICSBP expression, which may participate more directly in the TLR signaling pathway, via interaction with TRAF6 (49). Our results indicated a tight interplay between E. coioides IFN $\gamma$ s and TLR signaling pathways through induction of TRAF6 proteins. miR-146a is one of the most important and well-characterized miRNAs $(26,27,50)$ and is reported as a key regulator of the immune response through mediating TLR signaling. In mammals, the TLR4 signaling pathway can activate the expression of 

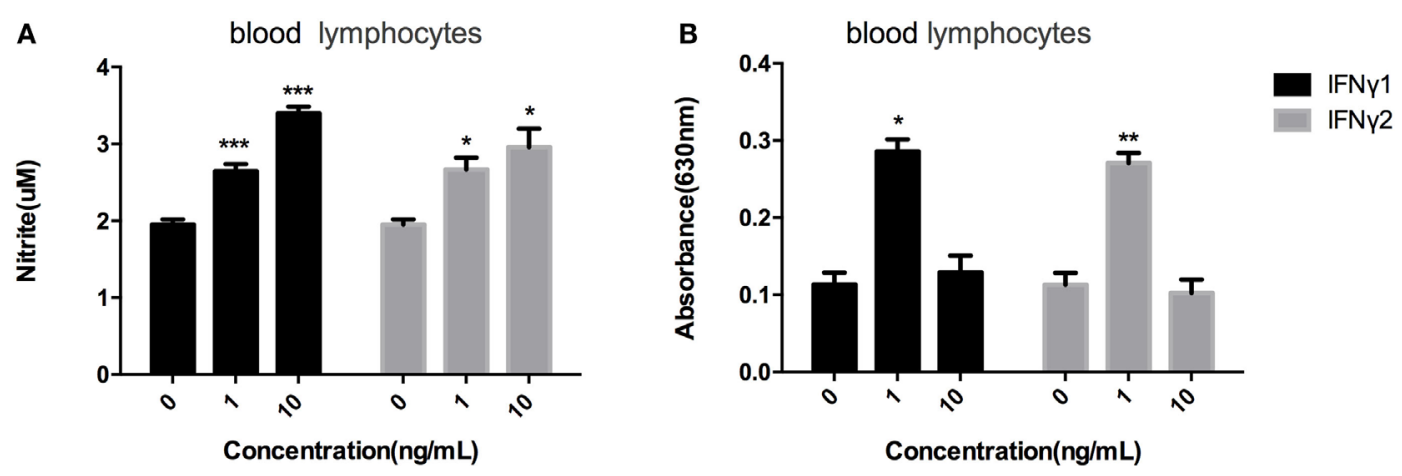

FIGURE 6 | rECIFN $\gamma 1$ and rECIFN $\gamma 2$ activated nitric oxide responses and respiratory burst response. (A) Nitric oxide production of Epinephelus coioides primary blood lymphocytes after stimulation with various concentrations of rEclFN $\gamma 1$ or rECIFN 2 for $72 \mathrm{~h}$ was determined using the Griess reaction and nitrite concentration was determined using a nitrite standard curve. (B) Respiratory burst activity of $E$. coioides primary blood lymphocytes after stimulation with various concentrations of rECIFN $\gamma 1$ or $r E C I F N \gamma 2$ for $18 \mathrm{~h}$ was detected. Each bar indicates the mean \pm SEM $(n=6)$. Statistical analysis was done using $t$-test. * ${ }^{* \star}$, and ${ }^{* \star *}$ : significant differences from control cells at the $p<0.05, p<0.01$, and $p<0.001$ levels, respectively.

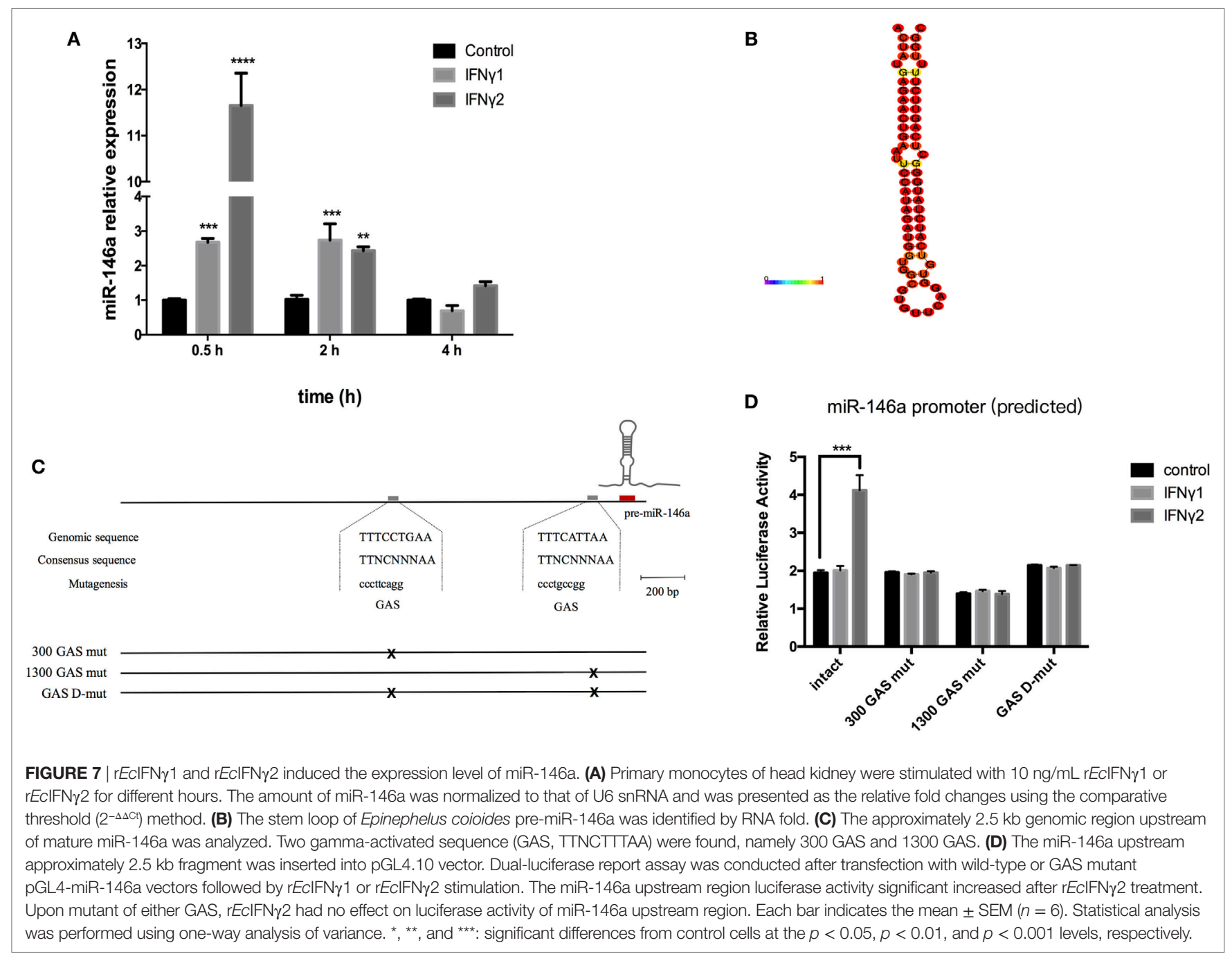

miR-146a mediated by NF- $\kappa B$ (30). Besides, miR-146a negatively regulates NF- $\kappa B$ activation through targeted inhibition of the signaling proteins of innate immune responses, such as NF- $\kappa B$ inducers TRAF6 and IRAK1 (51). In shellfish, miR-146a was identified in Pinctada martensii and represented a critical role in inflammatory response (52). In consistent with our results of 


\section{A

$$
\begin{array}{cccc}
\text { miR-146a } & 3^{\prime} & \text { GGUAGA-_-UACCUU--AAGUCAAGAGU } & 5^{\prime} \\
& & * \|||:|* * * * *||||: * * *|:|||||:| * * \\
\text { TRAF6 } & 5^{\prime} & \text { GCATTTTTGAGATGGAGCAGTTAGTTTTAT } & 3^{\prime}
\end{array}
$$

B

TRAF6 UTR

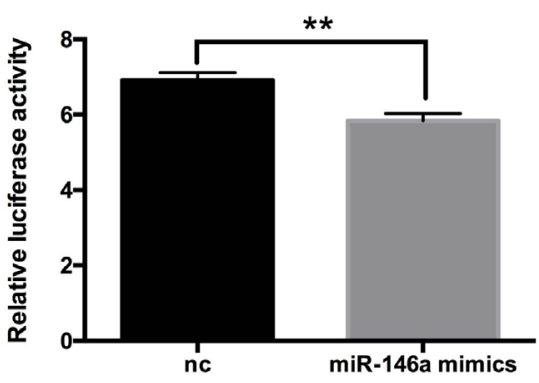

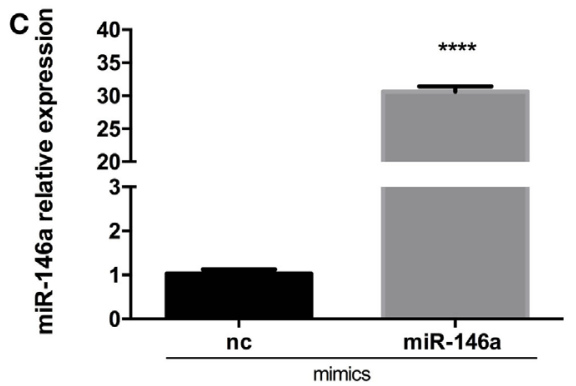

D mimics

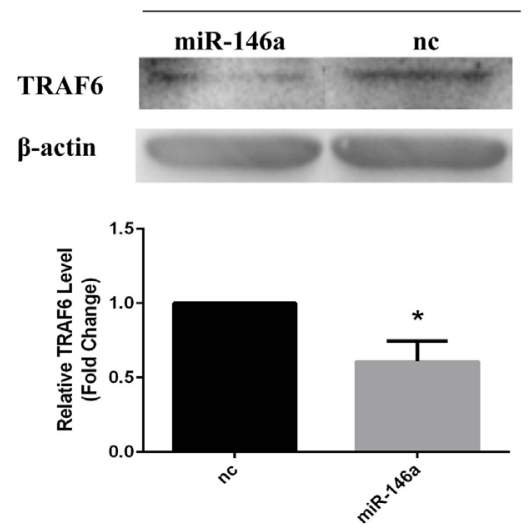

FIGURE 8 | Epinephelus coioides miR-146a may target TNF receptor-associated factor 6 (TRAF6). (A) The target site in TRAF6 was predicted by FINDTAR3. (B) A reporter construct that contain the firefly luciferase gene fused to $900 \mathrm{bp}$ of the $3^{\prime}$ untranslated region from TRAF6 containing putative miR-146 target site was obtained. miR-146a mimics induced the obvious downregulation of TRAF6 luciferase activity. (C) The E. coioides monocytes of head kidney were treated miR-146a mimics or negative control (nc). Then, the fold expression of miR-146a was calculated by the $2^{-\Delta \Delta C t}$ method using U6 as the reference gene, respectively. Compared with the nc, the expression of miR-146a significantly increased after miR-146a mimic treatment. (D) Treatment with miR-146a mimics triggered the weakening of the TRAF6 protein. The quantified graph was shown below the blots. Each bar indicates the mean \pm SEM $(n=6)$. Statistical analysis was performed using one-way analysis of variance. ${ }^{*},{ }^{* *}$, and ${ }^{* \star *}$ : significant differences from control cells at the $p<0.05, p<0.01$, and $p<0.001$ levels, respectively.
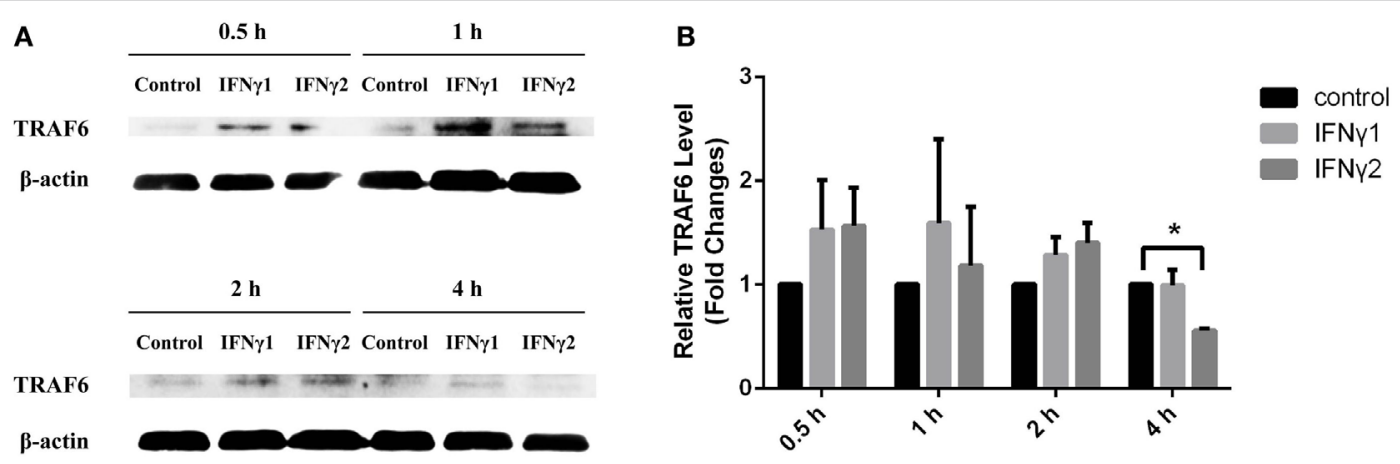

FIGURE 9 | rECIFN $\gamma 1$ and rECIFN $\gamma 2$ regulated TNF receptor-associated factor 6 (TRAF6) expression. (A) Primary monocytes of head kidney were stimulated with $10 \mathrm{ng} / \mathrm{mL} r E C I F N \gamma 1$ or $r E C I F N \gamma 2$ for different hours. The expression of TRAF6 protein was detected using western blot. The $\beta$-actin was used as an internal control. (B) Grayscale analysis was performed to semi-quantify the blots. *: significant difference from control blots at the $p<0.05$ levels $(n=3)$.

the $\mathrm{rEcIFN} \gamma 1$ and $\mathrm{rEcIFN} \gamma 2$ induction of miR-146a expression, miR-146a expression level was also upregulated when A375 cells were stimulated with IFN $\gamma$ in a short time (less than $12 \mathrm{~h}$ ) (53). It raised a question whether IFN $\gamma$ was involved in the regulation of miR-146a expression. What is more, the luciferase reporter assay further suggested that $\mathrm{rEcIFN} \gamma 2$ enhanced miR-146a upstream sequence luciferase activity, which was mediated by GAS site in miR-146a upstream region. Meanwhile, as the findings of previous researches in mammals, E. coioides miR-146a may target TRAF6, which is an adaptor in TLR pathway. Thus, we proposed that an IFN $\gamma 2$-miR-146a-TRAF6 negative loop may exist in teleost. In addition, overexpression of NF- $\mathrm{kB}$ p65 increased the miR-146a 


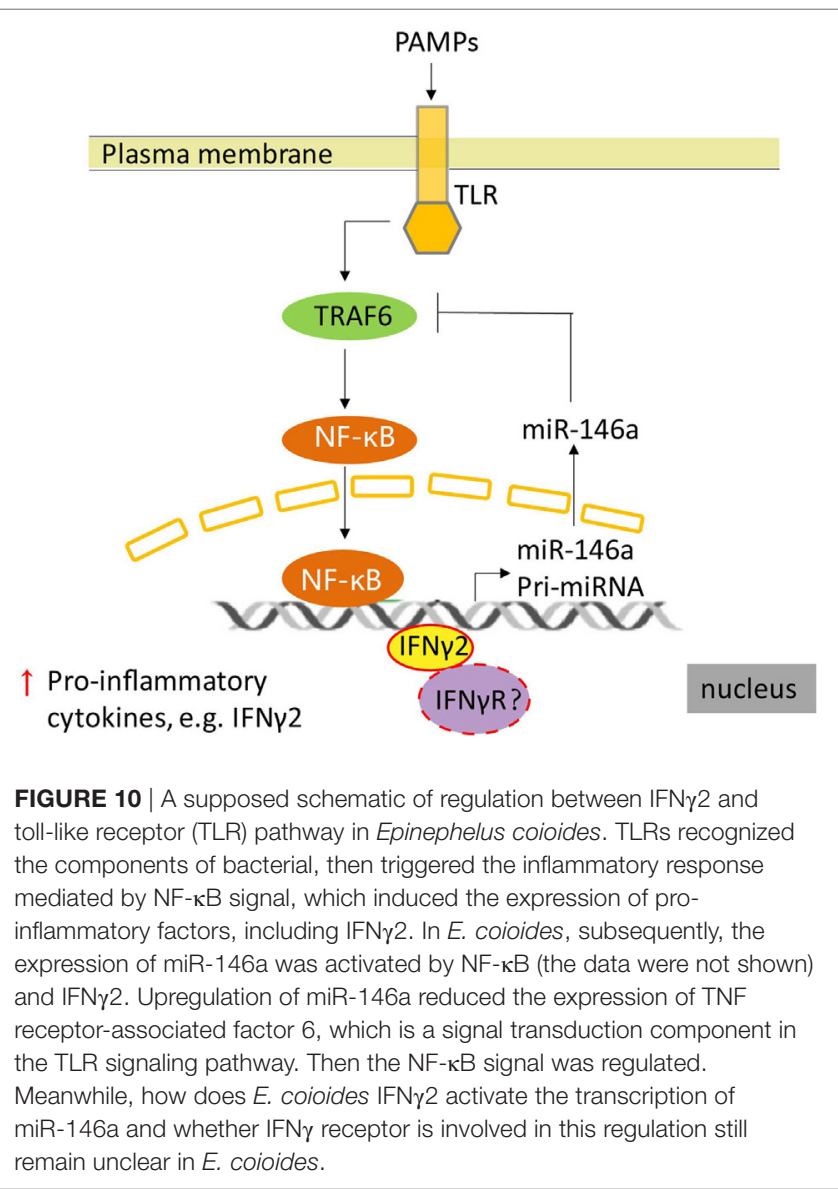

upstream sequence luciferase reporter activity, which is mediated by binding to NF- $\mathrm{KB}$ binding site in miR-146a upstream region (data not shown). These results also showed that the IFN $\gamma 2$ induced transcription of miR-146a in E. coioides relied on NF- $\mathrm{KB}$ as that of mammals.

Our previous study in T. nigroviridis indicated that although T. nigroviridis IFN $\gamma$ s were not able to protect T. nigroviridis from Vibrio parahaemolyticus infection, T. nigroviridis IFN $\gamma 1$ may promote an overwhelming inflammatory response, whereas
T. nigroviridis IFN $\gamma 2$ suppressed the inflammatory reaction promoted by $V$. parahaemolyticus infection (8). These further supported our speculation that $\mathrm{r} E \mathrm{IFN} \gamma 2$ would regulate immune response by IFN $\gamma 2$-miR-146a-TRAF6 negative regulation loop (Figure 10). A model of pathogen infection of E. coioides is needed to be established to further explore and characterize the E. coioides IFN $\gamma$ s function in vivo during immune response.

\section{ETHICS STATEMENT}

All animal experiments were conducted in accordance with the guidelines and approval of the Animal Research and Ethics Committees of Sun Yat-Sen University. All efforts were made to minimize suffering.

\section{AUTHOR CONTRIBUTIONS}

WP and D-QL conceived and designed the experiments; WP and YS performed most of the experiments; L-GH, XY, and R-ZL performed some experiments; Y-SL and XD contributed reagents/materials. $\mathrm{YZ}$ and $\mathrm{H}-\mathrm{RL}$ provided scientific advice; $\mathrm{WP}$ analyzed the data and wrote the manuscript. D-QL and G-FL revised and edited the manuscript. All authors reviewed the manuscript.

\section{ACKNOWLEDGMENTS}

We thank Jia-Nan He for his excellent technical assistance.

\section{FUNDING}

This work was supported by the National Natural Science Foundation of China (No.31001126), Guangdong Natural Science Foundation (No. 2014A030313214, 2015A030313069, 2015A030313409), Science and Technology Planning Project of Guangzhou (No.201607020014 and 201607010043), Modern Agriculture Talents Support Program (2016-2020), the Special Fund for Fisheries-Scientific Research of Guangdong Province (A201501A03, A201600A02) and the Fundamental Research Funds for the Central Universities (161gzd14, 161gpy35).

\section{REFERENCES}

1. Zimonjic DB, Rezanka LJ, Evans CH, Polymeropoulos MH, Trent JM, Popescu NC. Mapping of the immune interferon gamma gene (IFNG) to chromosome band 12q14 by fluorescence in situ hybridization. Cytogenet Cell Genet (1995) 71:247-8. doi:10.1159/000134119

2. Kaiser P, Wain HM, Rothwell L. Structure of the chicken interferon-gamma gene, and comparison to mammalian homologues. Gene (1998) 207:25-32. doi:10.1016/S0378-1119(97)00600-8

3. Qi Z, Nie P, Secombes CJ, Zou J. Intron-containing type I and type III IFN coexist in amphibians: refuting the concept that a retroposition event gave rise to type I IFNs. J Immunol (2010) 184:5038-46. doi:10.4049/jimmunol.0903374

4. Arts JAJ, Tijhaar EJ, Chadzinska M, Savelkoul HFJ, Kemenade BMLV. Analysis of carp interferon- $\gamma$ : evolutionary conservation of classical phagocyte activation. Fish Shellfish Immunol (2010) 29:793-802. doi:10.1016/j.fsi.2010. 07.010

5. Grayfer L, Belosevic M. Molecular characterization, expression and functional analysis of goldfish (Carassius aurutus L.) interferon gamma. Dev Comp Immunol (2009) 33:235-46. doi:10.1016/j.dci.2008.09.001

6. Grayfer L, Garcia EG, Belosevic M. Comparison of macrophage antimicrobial responses induced by type II interferons of the goldfish (Carassius auratus L.). J Biol Chem (2010) 285:23537-47. doi:10.1074/jbc.M109.096925

7. Zou J, Carrington A, Collet B, Dijkstra JM, Yoshiura Y, Bols N, et al. Identification and bioactivities of IFN-gamma in rainbow trout Oncorhynchus mykiss: the first Th1-type cytokine characterized functionally in fish. J Immunol (2005) 175:2484-94. doi:10.4049/jimmunol.175.4.2484

8. Peng W, Lu D-Q, Li G-F, Zhang X, Yao M, Zhang Y, et al. Two distinct interferon- $\gamma$ genes in Tetraodon nigroviridis: functional analysis during Vibrio parahaemolyticus infection. Mol Immunol (2016) 70:34-46. doi:10.1016/j. molimm.2015.12.004

9. Jung CY, Hikima J, Ohtani M, Jang HB, del Castillo CS, Nho SW, et al. Fish Shellfish Immunol (2012) 33:197-203. doi:10.1016/j.fsi.2012.04.015 
10. Sun B, Skjaeveland I, Svingerud T, Zou J, Jørgensen J, Robertsen B. Antiviral activity of salmonid gamma interferon against infectious pancreatic necrosis virus and salmonid alphavirus and its dependency on type I interferon. J Virol (2011) 85(17):9188-98. doi:10.1128/JVI.00319-11

11. Urban CF, Lourido S, Zychlinsky A. How do microbes evade neutrophil killing? Cell Microbiol (2006) 8:1687-96. doi:10.1111/j.1462-5822.2006. 00792.x

12. Ohta T, Ueda Y, Ito K, Miura C, Yamashita H, Miura T, et al. Anti-viral effects of interferon administration on sevenband grouper, Epinephelus septemfasciatus. Fish Shellfish Immunol (2011) 30:1064-71. doi:10.1016/j.fsi.2011.02.003

13. Nishizawa T, Takami I, Kokawa Y, Yoshimizu M. Fish immunization using a synthetic double-stranded RNA Poly(I:C), an interferon inducer, offers protection against RGNNV, a fish nodavirus. Dis Aquat Organ (2009) 83:115-22. doi:10.3354/dao02001

14. Ou-yang Z, Wang P, Huang X, Cai J, Huang Y, Wei S, et al. Immunogenicity and protective effects of inactivated Singapore grouper iridovirus (SGIV) vaccines in orange-spotted grouper, Epinephelus coioides. Dev Comp Immunol (2012) 38:254-61. doi:10.1016/j.dci.2012.07.004

15. Sturge CR, Benson A, Raetz M, Wilhelm CL, Mirpuri J, Vitetta ES, et al. TLR-independent neutrophil-derived IFN- $\gamma$ is important for host resistance to intracellular pathogens. Proc Natl Acad Sci U S A (2013) 110:10711-6. doi:10.1073/pnas.1307868110

16. Scharton-Kersten TM, Wynn TA, Denkers EY, Bala S, Grunvald E, Hieny S, et al. In the absence of endogenous IFN-gamma, mice develop unimpaired IL-12 responses to Toxoplasma gondii while failing to control acute infection. J Immunol (1996) 157:4045-54.

17. Sieger D, Stein C, Neifer D, van der Sar AM, Leptin M. The role of gamma interferon in innate immunity in the zebrafish embryo. Dis Model Mech (2009) 2:571-81. doi:10.1242/dmm.003509

18. Furnes C, Seppola M, Robertsen B. Molecular characterisation and expression analysis of interferon gamma in Atlantic cod (Gadus morhua). Fish Shellfish Immunol (2009) 26:285-92. doi:10.1016/j.fsi.2008.12.002

19. Bartel DP. MicroRNAs: genomics, biogenesis, mechanism, and function genomics: the miRNA genes. Cell (2004) 116:281-97. doi:10.1016/ S0092-8674(04)00045-5

20. Jackson RJ, Standart N. How do microRNAs regulate gene expression? Sci STKE (2007) 2007:re1. doi:10.1126/stke.3672007re1

21. O'Neill LA, Sheedy FJ, McCoy CE. MicroRNAs: the fine-tuners of toll-like receptor signalling. Nat Rev Immunol (2011) 11:163-75. doi:10.1038/nri2957

22. Bartel DP. Review microRNAs: target recognition and regulatory functions. Cell (2009) 136:215-33. doi:10.1016/j.cell.2009.01.002

23. Gregory RI, Yan K, Amuthan G, Chendrimada T, Doratotaj B, Cooch N, et al. The microprocessor complex mediates the genesis of microRNAs. Nature (2004) 208:2053-6. doi:10.1038/nature03120

24. Chendrimada TP, Gregory RI, KumaraswamyE, Norman J, Cooch N, Nishikura $\mathrm{K}$, et al. TRBP recruits the Dicer complex to Ago2 for microRNA processing and gene silencing. Nature (2005) 436:740-4. doi:10.1038/nature03868

25. Park H, Huang X, Lu C, Cairo MS, Zhou X. MicroRNA-146a and microRNA-146b regulate human dendritic cell apoptosis and cytokine production by targeting TRAF6 and IRAK1 proteins. J Biol Chem (2015) 290:2831-41. doi:10.1074/jbc.M114.591420

26. Saba R, Sorensen DL, Booth SA. MicroRNA-146a: a dominant, negative regulator of the innate immune response. Front Immunol (2014) 5:1-11. doi:10.3389/fimmu.2014.00578

27. Roos J, Enlund E, Jan-bernd F, Tews D, Holzmann K, Debatin K, et al. miR-146a-mediated suppression of the inflammatory response in human adipocytes. Sci Rep (2016) 6:38339. doi:10.1038/srep38339

28. Li M, Wang J, Fang Y, Gong S, Li M, Wu M, et al. microRNA-146a promotes mycobacterial survival in macrophages through suppressing nitric oxide production. Sci Rep (2016) 6:23351. doi:10.1038/srep23351

29. Cameron JE, Yin Q, Fewell C, Lacey M, Mcbride J, Wang X, et al. EpsteinBarr virus latent membrane protein 1 induces cellular microRNA miR-146a, a modulator of lymphocyte signaling pathways. J Virol (2008) 82:1946-58. doi:10.1128/JVI.02136-07

30. Taganov KD, Boldin MP, Chang K-J, Baltimore D. NF-kappaB-dependent induction of microRNA miR-146, an inhibitor targeted to signaling proteins of innate immune responses. Proc Natl Acad Sci U S A (2006) 103:12481-6. doi:10.1073/pnas.0605298103
31. Li Y, Shi X. MicroRNAs in the regulation of TLR and RIG-I pathways. Cell Mol Immunol (2013) 10:65-71. doi:10.1038/cmi.2012.55

32. Pacifico F, Crescenzi E, Mellone S, Iannetti A, Porrino N, Liguoro D, et al. Nuclear factor- $\kappa \mathrm{B}$ contributes to anaplastic thyroid carcinomas through up-regulation of miR-146a. J Clin Endocrinol Metab (2010) 95:1421-30. doi:10.1210/jc.2009-1128

33. Li S, Yue Y, Xu W, Xiong S. MicroRNA-146a represses mycobacteria-induced inflammatory response and facilitates bacterial replication via targeting IRAK-1 and TRAF-6. PLoS One (2013) 8:81483-81438. doi:10.1371/journal. pone. 0081438

34. Curtale G, Mirolo M, Renzi TA, Rossato M, Bazzoni F, Locati M. Negative regulation of toll-like receptor 4 signaling by IL-10-dependent microRNA-146b. Proc Natl Acad Sci U S A (2013) 110:11499-504. doi:10.1073/pnas.1219852110

35. Brameier M, Krings A, MacCallum RM. NucPred-predicting nuclear localization of proteins. Bioinformatics (2007) 23(9):1159-60. doi:10.1093/ bioinformatics/btm066

36. Yi S, Lu D, Peng W, Wang T, Zhang Y, Lin H. Differential expression profiling of spleen microRNAs in response to two distinct type II interferons in Tetraodon nigroviridis. PLoS One (2014) 9:1-12. doi:10.1371/journal.pone.0096336

37. Ma T, Jiang H, Gao Y, Zhao Y, Dai L, Xiong Q, et al. Microarray analysis of differentially expressed microRNAs in non-regressed and regressed bovine corpus luteum tissue; microRNA-378 may suppress luteal cell apoptosis by targeting the interferon gamma receptor 1 gene. J Appl Genet (2011) 52:481-6. doi:10.1007/s13353-011-0055-Z

38. Øverga AC, Nepstad I, Nerland AH, Patel S. Characterisation and expression analysis of the Atlantic halibut (Hippoglossus hippoglossus L.) cytokines: IL-1 b, IL-6, IL-11, IL-12 b and IFN $\gamma$. Mol Biol Rep (2012) 39:2201-13. doi:10.1007/ s11033-011-0969-x

39. Stolte EH, Savelkoul HFJ, Wiegertjes G, Flik G, Lidy Verburg-van Kemenade BM. Differsential expression of two interferon-gamma genes in common carp (Cyprinus carpio L.). Dev Comp Immunol (2008) 32:1467-81. doi:10.1016/j. dci.2008.06.012

40. Milev-Milovanovic I, Long S, Wilson M, Bengten E, Miller NW, Chinchar VG. Identification and expression analysis of interferon gamma genes in channel catfish. Immunogenetics (2006) 58:70-80. doi:10.1007/s00251-006-0081-x

41. Huang Z, Chen S, Liu J, Xiao J, Yan J, Feng H. IFNa of black carp is an antiviral cytokine modified with N-linked glycosylation. Fish Shellfish Immunol (2015) 46:477-85. doi:10.1016/j.fsi.2015.07.020

42. Razaghi A, Owens L, Heimann K. Review of the recombinant human interferon gamma as an immunotherapeutic: Impacts of production platforms and glycosylation. J Biotechnol (2016) 240:48-60. doi:10.1016/j.jbiotec.2016.10.022

43. Martin E, Nathan C, Xie QW. Role of interferon regulatory factor 1 in induction of nitric oxide synthase. J Exp Med (1994) 180:977-84. doi:10.1084/ jem.180.3.977

44. Cassatella MA, Bazzoni F, Flynn RM, Dusi S, Trinchieri G, Rossi F. Molecular basis of interferon-gamma and lipopolysaccharide enhancement of phagocyte respiratory burst capability. Studies on the gene expression of several NADPH oxidase components. J Biol Chem (1990) 265:20241-6.

45. Schroder K, Sweet MJ, Hume DA. Signal integration between IFN $\gamma$ and TLR signalling pathways in macrophages. Immunobiology (2006) 211:511-24 doi:10.1016/j.imbio.2006.05.007

46. Adib-Conquy M, Cavaillon JM. Gamma interferon and granulocyte/ monocyte colony-stimulating factor prevent endotoxin tolerance in human monocytes by promoting interleukin-1 receptor-associated kinase expression and its association to MyD88 and not by modulating TLR4 expression. J Biol Chem (2002) 277:27927-34. doi:10.1074/jbc.M200705200

47. Bosisio D, Polentarutti N, Sironi M, Bernasconi S, Miyake K, Webb GR, et al. Stimulation of toll-like receptor 4 expression in human mononuclear phagocytes by interferon-gamma: a molecular basis for priming and synergism with bacterial lipopolysaccharide. Blood (2002) 99:3427-31. doi:10.1182/blood. V99.9.3427

48. Dalpke AH, Eckerle S, Frey M, Heeg K. Triggering of toll-like receptors modulates IFN signalling: Involvement of serine 727 STAT1 phosphorylation and suppressors of cytokine signaling. Eur J Immunol (2003) 33:1776-87. doi:10.1002/eji.200323621

49. Zhao J, Kong HJ, Li H, Huang B, Yang M, Zhu C, et al. IRF-8/ interferon (IFN) consensus sequence-binding protein is involved in toll-like receptor (TLR) signaling and contributes to the cross-talk between TLR and 
IFN- $\gamma$ signaling pathways. J Biol Chem (2006) 281:10073-80. doi:10.1074/jbc. M507788200

50. Lu LF, Boldin MP, Chaudhry A, Lin LL, Taganov KD, Hanada T, et al. Function of miR-146a in controlling Treg cell-mediated regulation of Th1 responses. Cell (2010) 142:914-29. doi:10.1016/j.cell.2010.08.012

51. Liu R, Liu C, Chen D, Yang W, Liu X, Liu G, et al. FOXP3 controls an miR-146/ NFKB negative feedback loop that inhibits apoptosis in breast cancer cells. Cancer Res (2016) 75:1703-13. doi:10.1158/0008-5472.CAN-14-2108.FOXP3

52. Zheng Z, Liang J, Huang R, Du X, Wang Q, Deng Y, et al. Identification of a novel miR-146a from Pinctada martensii involved in the regulation of the inflammatory response. Fish Shellfish Immunol (2016) 54:40-5. doi:10.1016/j. fsi.2016.03.025

53. Reinsbach SE, Nazarov PV, Philippidou D, Schmitt M, Wieneckebaldacchino A, Muller A, et al. Dynamic regulation of microRNA expression following interferon $\gamma$-induced gene transcription. RNA Biol (2012) 9:978-89. doi:10.4161/rna.20494

Conflict of Interest Statement: The authors declare that the research was conducted in the absence of any commercial or financial relationships that could be construed as a potential conflict of interest.

Copyright $\odot 2018$ Peng, Sun, Li, He, Li, Liang, Ding, Yu, Zhang, Lin and Lu. This is an open-access article distributed under the terms of the Creative Commons Attribution License (CC BY). The use, distribution or reproduction in other forums is permitted, provided the original author(s) and the copyright owner are credited and that the original publication in this journal is cited, in accordance with accepted academic practice. No use, distribution or reproduction is permitted which does not comply with these terms. 